\title{
Karen Hollewand
}

\section{Het publieke geheim*}

\section{Seks en politiek in de late zeventiende eeuw}

In 1679 werd student Hadriaan Beverland opgepakt door de academische rechtbank in Leiden. In zijn studies over seks en zonde onthulde hij een publiek geheim: in de Nederlandse Republiek was seks enkel toegestaan binnen het huwelijk, maar Beverland liet zien dat de meeste mannen en vrouwen zich niets van deze regel aantrokken. Hij zette zich fel af tegen de magistraten van de Republiek, die dit seksuele gedrag negeerden, en beschuldigde hen van schaamteloze hypocrisie. Dit werd hem niet in dank afgenomen.

Op 4 december 1679 legde student Hadriaan Beverland (1650-1716) de volgende verklaring af voor de Academische Vierschaar van de Universiteit van Leiden: 'Ik ondergeschrevene Meester Adriaan Beverland, licentiaat in beijde de regten, belove bij dese op alle eer ende vromicheijt geen boeken, werken oft gescriften te sullen componeren, maken oft eenigsints uijt geven, ofte doen componeren, maken, schrijven oft drucken, veel min eenigsints divulgeren, contrarierende de heijlige schrifture eerbaarhijt oft goede seden...' ${ }^{1}$ De getuigenis sloot af met de belofte dat hij de straf die hem werd opgelegd door de universitaire rechtbank zou accepteren en de verklaring werd bekrachtigd met Beverlands handtekening. ${ }^{2}$

Studenten die in de problemen kwamen in de Nederlandse Republiek, bijvoorbeeld door geweldpleging, openbaar dronkenschap of ander buitensporig gedrag, hadden in de meeste universiteitssteden het recht om voor een speciale rechtbank te verschijnen. Dit privilege was erop gericht de zonen van de elite te beschermen en het was daarom gebruikelijk dat de zogenaamde Academische Vierschaar of Academieraad een milde straf oplegde. ${ }^{3}$ Dit gebeurde niet in het geval van Beverland: hij werd door de rechtbank verbannen uit de provincies Holland en Zeeland 'op peine van corporele straffe'. In 1678 en 1679 had Beverland drie studies gepubliceerd 
over lust, de erfzonde en de menselijke natuur en dit werd hem niet in dank afgenomen. Hij werd door de Vierschaar beschuldigd van het schrijven en publiceren van goddeloze en obscene werken, waarin hij de Bijbel zou hebben mishandeld en talloze 'dertelheeden' met gebruik van 'scurrile expressien ende exquisite bordeeltalen' zou hebben beschreven. ${ }^{4} \mathrm{Na}$ vijf weken in de studentengevangenis en een kort proces ontving Beverland zijn zware straf. Hij verliet de Nederlandse Republiek een paar maanden later en bracht de rest van zijn leven door in Engeland. ${ }^{5}$

In dit themanummer over seksualiteit en politiek mag een reflectie op Beverland, zijn rebelse studies en zijn verbanning eigenlijk niet ontbreken. Het is duidelijk dat een groep theologen van de Nederlandse Gereformeerde Kerk een grote rol speelde bij de arrestatie van Beverland door de Academische Vierschaar. Hij had hen beschuldigd van schijnheiligheid en onwetendheid als het ging om de tekst van de Bijbel en de aanwezigheid van seksuele lust in de menselijke natuur, wat ertoe leidde dat de theologen hard terug sloegen. Ze veroordeelden zijn studies, verzochten de Staten van Holland om in te grijpen en vervolgens zorgde deze machtige autoriteit ervoor dat hij werd opgepakt. ${ }^{6}$ Maar Beverland had het niet alleen aan de stok met de theologen, hij haalde ook fel uit naar andere machtige personen in de Nederlandse Republiek. Hij sprak verschillende professoren van zijn universiteit, magistraten van de stad Leiden en hooggeplaatste personen in de provinciale staten aan op hun houding tegenover seks. Seks buiten het huwelijk was officieel verboden in de Nederlandse Republiek, maar Beverland concludeerde dat menigeen zich hier niets van aan trok. 'Het is hier in Den Haag toegestaan voor ons om te drinken met jonge meisjes, ze te beminnen en met hen dineren," stelde hij en hij observeerde dat 'de meisjes van ons land alle bescheidenheid zodanig van hun brutale gezichten hebben laten verdwijnen, dat je ze nauwelijks kunt onderscheiden van prostituees, zoals ze dansen met hun trillende billen en uitgestrekte nekken.' ${ }^{8}$ Hij sprak de overheden aan op hun gewoonte om de dominantie van lust en het seksuele wangedrag dat de Nederlandse samenleving kenmerkte te ontkennen of te negeren en hij beschuldigde hen van schaamteloze hypocrisie.

Welke rol speelde deze opstandige houding van de jonge, getalenteerde Beverland nu eigenlijk in zijn proces? Wat verweet hij de wereldlijke overheden van de Nederlandse Republiek in het algemeen en bepaalde gezaghebbers in het bijzonder? Had hij zijn zware straf misschien niet zozeer aan de theologen maar aan zijn bonje met hooggeplaatste staatslieden te danken? 
Seks en zonde

In 1669, op zijn achttiende, verliet Beverland zijn geboorteplaats Middelburg om te gaan studeren aan de Universiteit van Franeker. In de jaren die volgden stond hij als student ook ingeschreven bij de universiteiten van Leiden en Utrecht en in 1677 behaalde hij zijn doctoraat in de rechten. In 1678 en 1679 publiceerde hij zijn eerste studies. ${ }^{9}$ In De Peccato Originali (Over de Erfzonde), dat werd uitgegeven in drie verschillende edities, definieerde Beverland seksuele lust als de erfzonde en hij leidde hieruit af dat de menselijke natuur beheerst werd door seksuele driften. ${ }^{10}$ 'The whole world suffers from this illness, because the whole of mankind has been formed from the same blood (whatever Pelagius may proclaim). Eve was deceived and Adam was seduced by her, so that sin entered the world through one person and through sin [entered] unavoidable death. Thus death spread among all, since all have sinned." ${ }^{11}$ In zijn tweede boek De Stolatae Virginitatis Iure (Over het Maagdenrecht) richtte Beverland zich in het bijzonder op de lust van de vrouw. ${ }^{12}$ Beide studies waren echter slechts inleidingen op het omvangrijke werk dat hij aan het afronden was in deze periode: in zijn 'De Prostibulis Veterum' ('Over Prostitutie in de Oudheid'), dat hij uiteindelijk nooit afgemaakt heeft, zou hij alle bevindingen van zijn onderzoek naar seksualiteit uit de doeken doen. ${ }^{13}$

Beverland baseerde zijn argument op de tekst van de Bijbel, maar bovenal putte hij uit zijn verreikende kennis van de klassieke literatuur. Bijna elke zin in zijn De Peccato, De Stolatae en 'De Prostibulis' bevatte een referentie naar een Griekse of Romeinse auteur, een antiek verhaal of een personage 
uit de klassieke oudheid. ${ }^{14}$ Hij richtte zich niet alleen op het verleden: seks domineerde, in zijn ogen, ook de bevolking van de zeventiende-eeuwse Nederlandse Republiek. Het maakte niet uit of je man of vrouw, oud of jong, ketter of christen was, wanneer je was geboren of op welke plek: na de zondeval van Adam en Eva, die seks met elkaar gehad hadden in de Tuin van Eden, beheerste seksuele lust de universele menselijke natuur, altijd en overal. 'The flesh desires in opposition to the spirit and the spirit in opposition to the flesh, so that by nature all people both privately and publicly seem to be inclined to the enjoyment of lust and alienated from God and chastity. They are neither chaste, nor virtuous, nor respectable, but nor are they fornicators or whores; they are everything together. ${ }^{35}$

Door de dominantie van seks in zijn eigen samenleving te benadrukken, openbaarde Beverland een publiek geheim. In de Nederlandse Republiek was het niet toegestaan om buiten het huwelijk seks te hebben. Je mocht enkel de liefde bedrijven met je wettige man of vrouw, gericht op het verwekken van een kind. Dit betekende dat seks voor of buiten het huwelijk officieel verboden was, evenals bepaalde standjes, seks met jezelf of het bezoeken van een prostituee. Net als in de meeste andere landen in West-Europa waren deze wetten en regels omtrent seksueel gedrag gebaseerd op het christelijke geloof: seks was een zonde, lust was gevaarlijk voor het individu en voor de gemeenschap en daarom waren seksuele relaties alleen toegestaan in relatie tot reproductie. Hield je je niet aan deze regels dan kon je een boete krijgen, in de gevangenis terecht komen, verbannen worden uit de gemeenschap of zelfs ter dood worden veroordeeld. ${ }^{16}$ Ondanks de strenge voorschriften op het gebied van seksueel gedrag hebben de studies van verschillende historici laten zien dat veel mannen en vrouwen er toch voor kozen om seks te hebben buiten het huwelijk: seks tussen (nog) niet-getrouwde koppels kwam veel voor, de markt voor pornografie was aanzienlijk en in Nederlandse steden in de zeventiende eeuw was de aanwezigheid van prostitutie geen uitzondering maar een gegeven. ${ }^{17}$

Beverland beschreef het 'buitensporige' gedrag van zijn tijdgenoten en benadrukte dat 'the human sin, to which we are prone by nature, [is] a guide and companion who cannot be absent, for even the matter itself proceeds without a guide and without a companion. The road to these vices is not just inclined downward; it plunges headlong downhill. A beautiful girl is soon admired and easily desires vile things. Nobody has shame. Everyone freely asks, gives, and presents. Wandering through their whole life they take pleasure in these sins. ${ }^{18}$ Wetten, straffen en preken waren nutteloos, 
betoogde hij: lust was nu eenmaal de erfzonde en tegen de dominantie van seksuele driften was dus niets te beginnen. 'This inborn sin will not be washed away by any rivers, seas, or even the immense ocean. Countless examples rush to our aid in this argument of ours, not against their will but entirely freely. ${ }^{19}$ In zijn studies presenteerde hij een oplossing voor het probleem van seksuele lust, voor de grote kloof tussen de realiteit en de regels: seksuele vrijheid. De drang tot seks was onontkoombaar en daarom was het beter om met lust te leren omgaan en om van het onvermijdelijke te genieten. Deze seksuele vrijheid was echter niet voor iedereen weggelegd. Alleen de beoogde lezers van zijn studies, hoogopgeleide mannen van de elite, konden deze verantwoordelijkheid dragen, stelde Beverland. ${ }^{20}$

Door een publiek geheim te bespreken, namelijk dat ondanks de strikte regelgeving seks buiten het huwelijk veel voorkwam in vroegmodern Europa, viel Beverland in zijn eerste studies indirect de overheden in de Republiek aan. Hij zag zelf al aankomen dat zijn ideeën waarschijnlijk niet in goede aarde zouden vallen.

Zo schreef hij in zijn De Peccato dat: 'Without a doubt the severe Cato's with their sour faces, who subsist on cumin, mustard, and vinegar, will accuse me of sacrilege, because a bridegroom should save these shameful acts of adultery for his bride.. ${ }^{21}$ De radicale oplossing die Beverland voorstelde om het probleem van lust op te lossen stond lijnrecht tegenover het beleid van stedelijke en provinciale overheden, die er juist op gebrand waren om seksueel wangedrag uit te bannen. Hij provoceerde hen niet alleen door de dominantie van lust uitgebreid te bespreken, hij richtte zijn pijlen ook direct op bepaalde machthebbers.

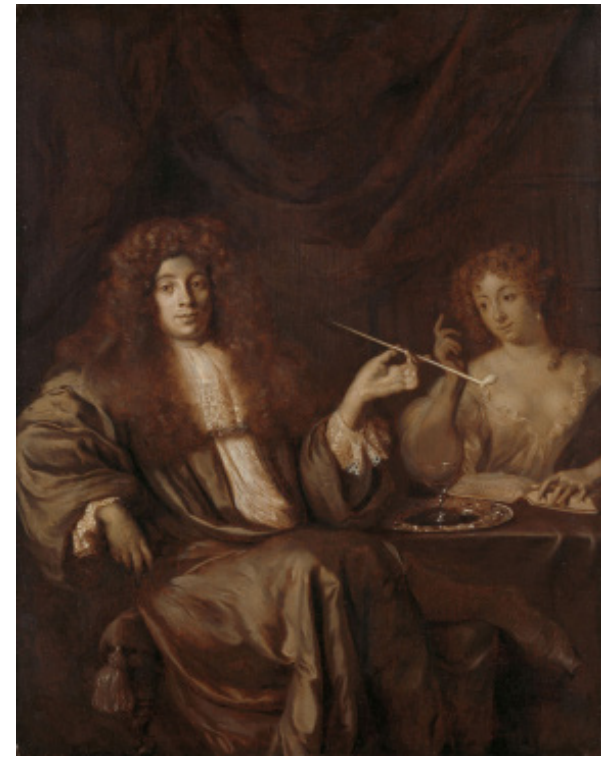

Afbeelding 2: portret van Hadriaan Beverland met prostituee, toegeschreven aan Ary de Vois, ca. 1676. (Rijksmuseum) 


\section{Zeeuwse eerlijkheid en Leidse hypocrisie}

Beverland haalde talloze voorbeelden aan in zijn studies om te laten zien dat seks overal te vinden was: in het meest heilige boek, in Griekse en Romeinse teksten en in zijn eigen samenleving. Dit deed hij niet alleen om zijn lezers te vermaken: het was zijn doel om hen een spiegel voor te houden en de waarheid te vertellen over de dominantie van seksuele driften in de menselijke natuur: 'Our conscience and the light of our heart has demonstrated that our view is more in line with the utterances of God, and who would not notice and find such a massive and common defect in his own vase somewhere. But what need is there of further words? "The truth of words does not need assistance." 22 In verschillende brieven, gericht aan vrienden die hem meer dan eens adviseerden om gas terug te nemen, legde Beverland uit dat hij, vanwege zijn oprechte karakter, niet anders kon: 'Ik ben geen vleier zoals die parasieten, want ik ben een Zeeuw. ${ }^{23}$ Hij was ervan overtuigd dat alleen door de naakte waarheid te vertellen en de dingen bij de naam te noemen het probleem van seksuele lust opgelost kon worden. ${ }^{24}$

Beverland zette zich fel af tegen tijdgenoten die de dominantie van seks niet wilden inzien en noemde hen hypocriet. Hij richtte zich bijvoorbeeld op de hooggeplaatste heren in de academie en in het stadsbestuur van Leiden. Zij waren allen goed op de hoogte van de prostitutie in de stad, de seksuele escapades van jonge mannen en vrouwen en de populariteit van pornografisch materiaal, maar ze kozen ervoor de andere kant op te kijken. Beverlands aanval op deze schijnheiligheid kwam op veel punten overeen met de kritiek die werd geuit in verschillende filosofische werken van tijdgenoten. Baruch Spinoza, Lodewijk Meijer en Adriaan Koerbagh zetten zich op eenzelfde wijze af tegen de hypocrisie die ze observeerden om zich heen. ${ }^{25}$ Beverland vormde echter een uitzondering in deze groep radicale denkers: hij concentreerde zich als enige op seksuele lust. Door de nadruk op het belang van seks in de samenleving zijn Beverlands werken ook te vergelijken met een heel ander vroegmodern genre. In verschillende zeventiende-eeuwse pornografische teksten herkennen we dezelfde afwijzende houding tegenover een hypocriete maatschappij: schrijvers bekritiseerden vaak de geestelijke en wereldlijke overheden en benadrukten dat zij, door over seks te schrijven, de waarheid openbaarden. In populaire werken als L'Ecole des Filles (1655) en Vénus dans le cloître (1683) maar ook verschillende Nederlandse romans, zoals De Doorluchtige Daden van Jan Stront (1684) en De Leidsche Straatschender (1679) werd het schijnheilige ideaal van kuisheid belachelijk gemaakt en de 
hypocrisie van tijdgenoten aangevallen. ${ }^{26}$

Beverland nam in zijn werken geen blad voor de mond: hij richtte zich direct tot de 'idioten' die de waarheid ontkenden en ontweken. ${ }^{27}$ Nog voor hij gearresteerd werd door de universitaire rechtbank stelde hij dat zijn critici hem naar beneden haalden met beledigingen omdat 'I had execrated their salacious wickedness with obscene words.... As long as it is not licit for them to emulate someone's achievement, they envy it and they spare nobody but themselves and they have attacked me in particular with monstrous nonsense of falsehoods. ${ }^{28}$ In het naschrift van de eerste editie van zijn De Peccato richtte Beverland zich tot God om hem bij te staan in zijn strijd tegen deze bedriegers: 'Free me from the unlearned prevaricators, who have sharpened their tongues like snakes. May I remove the detestable mask of hypocrisy of some people with ornate eloquence and pure hand to the greater glory of your name and the edification of our salvation... May I rush against iniquities with my virtue, and may I not fear the face of the powerful, and may I always understand that injustice is the acquisition of death. Supply me with the weapons to do this.' ${ }^{29}$ Tijdens zijn rechtszaak verslechterde de verhouding tussen Beverland en de leden van het stadsbestuur van Leiden, die aandrongen op zijn veroordeling, in het bijzonder. Hij was van mening dat de meeste van hen te dom waren om zijn ideeën te begrijpen: 'If the lawsuit had been pursued in my hometown, the outcome would have been very different. Our magistrates are usually not chosen from artisans, gardeners, and shopkeepers. Consul Schuyl, one of the judges, was a man with undeveloped knowledge of the Latin language and a trader in manure. The others were merchants of the market and wine sellers. Behold these suitable judges of my work! ${ }^{30}$

Naast Herman Schuijl haalde Beverland ook uit naar Pieter Burgersdijck en Johan Jeroenszoon van der Marck: deze drie mannen hadden een belangrijke functie in het stadsbestuur en waren als afgevaardigden vertegenwoordigd in de Academische Vierschaar. ${ }^{31} \mathrm{Zij}$ deden, volgens Beverland, wel erg hun best om ervoor te zorgen dat hij een zware straf zou krijgen. Ze probeerden bijvoorbeeld valse bekentenissen uit te lokken door hem dronken te voeren. ${ }^{32}$ Ook de promotor van de rechtbank, de rijke patriciër Johan Dirckszoon van Vesanevelt, die verantwoordelijk was voor zijn arrestatie en de aanklacht, werd hard aangevallen. ${ }^{33}$ Beverland noemde hem Vesanus (de waanzinnige) en hij schreef in een brief aan Nicolaas Heinsius het volgende over zijn arrestatie door Vesanevelt en de stadswacht: 'de officier van justitie, die via een vies steegje ten tonele was verschenen, [stond] daar met opengesperde muil met zijn ellendige rietstokje te dreigen. Als een strenge Cato met een 
pruillip bleef hij maar dreigementen uitkramen met zijn neus als van een neushoorn, als een koeherder met arrogante blik stond hij daar met getrokken theta in het rond te zwaaien, maar ik was niet bang van de opgeblazen muilen van die gekroonde bende en evenmin van die afschuwelijke kerels vol vooroordelen en smadelijke boersheid. ${ }^{34}$ Niet alleen de leden van de rechtbank moesten het ontgelden: Beverland had ook ruzie met één van de machtigste mannen van de Republiek. In zijn brieven vervloekte hij Gaspar Fagel, de raadpensionaris van Holland, die vanaf het begin bij zijn rechtszaak betrokken was geweest. Fagel had in juli 1679, tijdens een synode van de Nederlandse Gereformeerde Kerk, Beverlands werken ter sprake gebracht: 'bij den heere raetpensionaris Fagel, als afsonderlijck en alleen, op het goetvonden van de heer Fagel, bij de regeeringe van Rotterdam; maecken oock bekent dat uytgekomen is een vuyl en lasterlijck tractaet, gemaeckt van eenen Adrianus Beverlandt, geintituleert de "Peccato Original". ${ }^{35}$ In september 1679 was Fagel waarschijnlijk ook degene geweest die het rekest van de synode, om Beverland aan te pakken, geïntroduceerd had in de Staten van Holland, die vervolgens aan de universitaire rechtbank van Leiden de opdracht gaven om Beverland te arresteren. ${ }^{36}$

Hoewel hij ieder van deze machtige mannen iets specifieks te verwijten had, was het duidelijk waarom Beverland deze magistraten als groep niet kon uitstaan. De leden van het stadsbestuur, maar ook de meerderheid van de academici en de leden van de Staten van Holland, waren, volgens Beverland, enkel geïnteresseerd in hun rijkdom en reputatie: 'the stupid herd believes in investing their strength not in their erudition but in their wealth. I resent how often I see that wise men beg for money and pieces of silver like beasts... I do not doubt that if all honourable men became acquainted with supporting themselves with bread and polenta instead of the insult of wealth (like Dodwell in England), adorned with the scanty persistence of frugality, they would actually be able to debate with the gods themselves. ${ }^{37}$ Beverland had besloten niet mee te doen met dit schouwspel en verkoos eerlijkheid boven de hypocrisie van vele van zijn tijdgenoten. Om de invloedrijke theologen te vriend te houden, en hierdoor snel carrière te kunnen maken, sloten de meeste mannen om hem heen hun ogen voor de waarheid en keerden zich tegen hem, zijn werken en zijn ideeën over seks. 'They say that I have destroyed modesty, that I have been defeating shame and have violated the immature ears of young men with the dirt of the most wanton words. ${ }^{38}$ Ondanks zijn inspanningen bleven zijn tegenstanders, die volgens Beverland zelf vaak genoten van seks buiten het huwelijk, ontkennen dat hij 
gelijk had: 'Whatever you say to these idiots, it will be in vain. Redeemed for their vices by not a single virtue they go to lurking-places outside the walls, so that they can move their loins in a joint motion with courtesans, whores, and cheap prostitutes smelling like fish and vegetables.... These are the men who attack me with their forked tongue. ${ }^{39}$

\section{Conclusie}

In de lente van 1680 arriveerde Beverland in Engeland. Na zijn vrijlating uit de studentengevangenis in december 1679 was hij uitgeweken naar Utrecht, maar hij besloot uiteindelijk het Kanaal over te steken. De storm rond zijn studies en rechtszaak was na een aantal maanden, door de kritiek van zijn tegenstanders maar ook door Beverlands eigen gedrag, nog niet gaan liggen en hij wilde het risico niet lopen om opnieuw opgepakt te worden. Hiernaast kon hij in Engeland rekenen op de steun van zijn stiefvader Bernhard de Gomme, een invloedrijk militair ingenieur, en goede vriend Isaac Vossius, een rijke geleerde. Hij kwam in Engeland niet opnieuw in de problemen: niet zozeer omdat er in deze omgeving met meer sympathie werd gereageerd op zijn ideeën, maar omdat hij afzag van het publiceren van zijn 'De Prostibulis' of andere studies over seks en zonde. Hij legde zich toe op het bestuderen klassieke teksten en het (ver)kopen van boeken en kunst voor vermogende Engelse heren. ${ }^{40}$

In 1693 ontving Beverland een pardon voor zijn straf van Willem III, koning van Engeland en stadhouder van de Republiek. ${ }^{41}$ Zijn verbanning was opgeheven maar Beverland keerde niet terug naar huis. Hij had vijftien jaar eerder zijn studies opgesteld in moeilijk Latijn en uitgegeven voor een klein, geleerd publiek, maar door het pikante onderwerp en zijn rechtszaak waren zijn naam en werken bij velen bekend. Hij was ervan overtuigd dat het moeilijk zou zijn om zijn leven in de Republiek weer op te pakken, na alles wat er was gebeurd. ${ }^{42}$ Hij schreef aan zijn goede vriend Jacobus Gronovius in 1694: 'Ik heb mij erop toegelegd mijn slechte reputatie uit de wereld te helpen. Ik verlang vurig de rookpluimen van mijn vaderland weer te zien, maar ik vrees dat de magistraten en de theologen mij nog altijd zullen lastigvallen. U weet immers dat hun haat nóóit dooft. ${ }^{43}$ Beverland concludeerde een jaar later: 'Het is moeilijk om mijn aanzien te herwinnen met de brokstukken van een goede reputatie die verwoest werd. ${ }^{34}$

Met zijn uitgesproken stijl, radicale argument en directe aanvallen op de wereldlijke en seculiere overheden had Beverland weinig vrienden 
gemaakt. Seks en politiek stonden op gespannen voet in de zeventiendeeeuwse Nederlandse Republiek. Ondanks de simpele regels wat betreft seksuele activiteiten, die alleen plaats mochten vinden tussen man en vrouw in het huwelijk, deelden veel koppels het bed met elkaar voor hun trouwen, kozen mannen en vrouwen ervoor seks buiten het huwelijk te hebben en waren zowel prostitutie als pornografie overal te vinden in de Nederlandse steden. In verschillende studies heeft Inger Leemans laten zien dat de Republiek fungeerde als 'de seksshop van Europa' in deze periode: Amsterdamse uitgevers speelden slim in op de populariteit van pornografische werken en publiceerden zowel Nederlandse vertalingen van buitenlandse werken als oorspronkelijk Nederlandstalige romans. ${ }^{45}$ Door de dominantie van lust uitvoerig te bespreken, van de oorsprong in het Paradijs tot de Nederlandse samenleving van de zeventiende eeuw, legde Beverland zijn vinger op de zere plek. Hij bracht een publiek geheim ter sprake dat de prominenten van de Republiek liever ontkenden en negeerden. Bovendien sprak hij de magistraten rechtstreeks aan op hun gedrag: hij beschuldigde hen van hypocrisie, aangezien vele van hen regelmatig genoten van seks buiten het huwelijksbed maar hem beschuldigden van het verspreiden van obsceniteiten. Beverland was op zoek naar een oplossing, maar zijn tegenstanders verkozen hun geld en carrière boven de waarheid: 'The persons watching over their riches and honour, they refuse to expose themselves to danger: but I preferred to use my mastery of my free will and my fate, and to tame the barbarity of the stupid. ${ }^{36}$

Welke rol speelden de seculiere overheden nu in zijn proces? Beverland was er tot zijn dood van overtuigd dat de theologen van de Nederlandse Gereformeerde Kerk verantwoordelijk waren voor zijn verbanning en dit lijkt deels te kloppen. Zij waren de eersten die zijn studies officieel afkeurden en stuurden aan op een veroordeling en een zware straf. Het is echter duidelijk dat ook de leden van het stadsbestuur van Leiden en van de Staten van Holland zich met zijn zaak bemoeiden. ${ }^{47}$ De Staten van Holland betaalden in 1575 voor de oprichting van de Universiteit van Leiden en hadden hierdoor veel te vertellen binnen deze academische instelling, ook als het ging om de academische rechtspraak. In de zaak Beverland was het daarom mogelijk dat raadspensionaris Gaspar Fagel, hoewel hij niet als rechter was aangewezen, op de achtergrond toch een grote rol speelde. Uit de documenten van zijn proces blijkt dat de mannen die Beverland indirect in zijn werken aansprak op hun hypocrisie, en die hij bij naam noemde in zijn brieven, instemden met zijn veroordeling en verantwoordelijk waren voor de strafmaat. $\mathrm{Ze}$ 
waren Beverland, een rebelse student die hen direct had aangevallen en die een ongemakkelijke waarheid op een gedurfde manier had blootgelegd, liever kwijt dan rijk.

Beverlands werk vertoont, als het gaat om de afkeuring van hypocrisie, aan de ene kant gelijkenissen met de ideeën van radicale denkers als Spinoza en Koerbagh. Aan de andere kant zijn er ook overeenkomsten te vinden tussen zijn studies en pornografische romans die in deze periode verschenen: beide waren namelijk gericht op het openbaren van de dominantie van seks in de samenleving. De combinatie van geleerde kennis, een provocerende stijl en de promotie van seksuele vrijheid in Beverlands werken was echter uniek en bracht hem in grote problemen. In de achttiende eeuw kwam er in Europa langzaam meer ruimte voor dergelijke ideeën over seksuele lust en vrijheid. Denkers als Bernard Mandeville en Alberto Radicati bespraken de seksuele moraal openlijk in relatie tot de menselijke natuur, persoonlijke vrijheid en de samenleving. ${ }^{48}$ Beverlands argument kreeg in deze context een tweede leven: in Franse en Duitse edities van zijn De Peccato werden zijn ideeën in een ander jasje gestoken en gelezen door een nieuw publiek. ${ }^{49} \mathrm{Hij}$ maakte het zelf niet meer mee. Beverland stierf in Londen, arm en alleen, in 1716. De volgende tekst, geschreven door dichter David van Hoogstraten, kwam niet op zijn grafsteen te staan, maar vatte wel de visie van veel van zijn tijdgenoten goed samen:

Hoe rijk waert gij verzien van hemelglans en stralen Die als een meidau op u neder quamen dalen; Zoo gy niet, spelende met u geleerd verstand, Had met den voet geschopt de gaven van Gods hand. Wat is geleertheid, van Godsvruchtigheid versteken? Een kostelyck vertrek, om slangen op te queken. ${ }^{50}$

\section{Noten}

* Mijn dank gaat uit naar Teunie Rouwendal voor haar assistentie bij het onderzoek voor dit artikel. 


\section{Hollewand}

1. Nationaal Archief, Vierschaar der Universiteit te Leiden, Crimineele klachtboeken. 1631-1810, part 13, Litt. E, 1647-1695, 116c. Voor meer over Beverlands rechtszaak, zie: Karen Hollewand, The Banishment of Beverland: Sex, Scripture, and Scholarship in the seventeenth-century Dutch Republic (Leiden: Brill, 2019), 32-38, 257.

2. Idem.

3. Voor meer over de Academische Vierscharen in de Republiek, zie: W. Otterspeer, Het bolwerk van de vrijheid. De Leidse universiteit, 1575-1672. Groepsportret met Dame Volume I (Amsterdam: Bert Bakker, 2000), 123-36; Idem, De vesting van de macht. De Leidse universiteit, 1673-1775. Groepsportret met Dame Volume II (Amsterdam: Bert Bakker, 2002), 161-78; F.A.J. van der Ven, 'Enige opmerkingen over de academierechtspraak te Groningen. Een geval van niet-exclusieve gelding van het stellige recht', in Groninger Opmerkingen en Mededelingen, volume 12 (1995): 70-115; A.C.J. de Vrankrijker, Vier eeuwen Nederlandsch studentenleven (Voorburg: Boot, 1936), 149-171.

4. Nationaal Archief, Vierschaar der Universiteit te Leiden, Crimineele klachtboeken. 1631-1810, part 13, Litt. E, 1647-1695, 115v.

5. Voor meer over Beverlands leven, zie: Hollewand, The Banishment, 20-40, 228-240.

6. Zie: Hollewand, The Banishment, 42-108, 241-248.

7. Hadriaan Beverland, De Stolatae Virginitatis Iure (Leiden, 1679), 150. Deze en de andere citaten uit Beverlands brieven en studies in dit artikel zijn vertaald uit het Latijn.

8. Beverland, De Stolatae, 114.

9. Zie: Hollewand, The Banishment, 20-28.

10. Hadriaan Beverland, Peccatum Originale (Leiden, 1678); Idem, De Peccato Originali (Leiden, 1679); Idem, Poma Amoris (Leiden, 1679). De laatste editie, die gepubliceerd werd toen Beverland gevangen zat, vinden we enkel terug in zijn brieven: er is geen exemplaar bewaard gebleven.

11. Beverland, De Peccato, 50-51. De citaten uit deze studie zijn vertaald van het Latijn naar het Engels en maken deel uit van: Hadriaan Beverland's De Peccato Originali (On Original Sin, 1679): a critical edition and translation, Karen Hollewand en Floris Verhaart (Leiden: Brill, verwacht 2021).

12. Beverland, De Stolatae.

13. Dit werk werd nooit gepubliceerd en vandaag de dag hebben we enkel toegang tot het eerste boek, dat bewaard wordt in de Speciale Collecties van de Universiteitsbibliotheek van Leiden (BPL 1994).

14. Zie: Hollewand, The Banishment, 109-124.

15. Beverland, De Peccato, 33.

16. Zie: Manon van der Heijden, Huwelijk in Holland: stedelijke rechtspraak en kerkelijke tucht, 1550-1700 (Amsterdam: Bakker, 1998), 30-76; Lotte van de Pol, Het Amsterdams Hoerdom: Prostitutie in de Zeventiende en Achtiende Eeuw (Proefschrift, Erasmus Universiteit Rotterdam, Amsterdam: Wereldbibliotheek, 1996), 75-6, 157-70; Donald Haks, Huwelijk en Gezin in Holland in de 17de en 18de Eeuw: Processtukken en Moralisten over Aspecten van het laat 17de- en 18de-Eeuwse Gezinsleven (Proefschrift, University of Leiden, Assen: Van Gorcum, 1982), 70-104. 
17. Zie: Van de Pol, Het Amsterdams Hoerdom, 181, 196-225, 343-55; Van der Heijden, Huwelijk, 11-32, 70-74, 142-164; Inger Leemans, Het woord is aan de onderkant. Radicale ideeën in Nederlandse pornografische romans 1670-1700 (Proefschrift Universiteit van Utrecht, Nijmegen: Vantilt, 2002), 13-32, 147-72; W.W. Mijnhardt, 'Politics and Pornography in the Seventeenth- and Eighteenth Century Dutch Republic', in Lynn Hunt (ed.), The Invention of pornography: obscenity and the origins of modernity, 1500-1800 (New York: Zone Books, 1993): 283-300.

18. Beverland, De Peccato, 64.

19. Ibidem, 94.

20. Hollewand, The Banishment, 119-227.

21. Beverland, De Peccato, 41. Beverland gebruikte vaak de term Cato (een referentie naar de conservatieve Romeinse staatsman Cato de Oudere of Cato de Censor) om zijn tegenstanders aan te duiden.

22. Beverland, De Peccato, 58. De quote komt uit de Codex Justinianus (Corpus Juris Civilis), boek 2, deel 31.1.

23. Beverland aan Jacobus Gronovius, 1702, in Universiteitsbibliotheek München, Beverlands Correspondentie met Jacobus Gronovius, 2e Cod. Misc. 627, brief no. 26. Deze collectie brieven wordt van nu af aangeduid als EG. Voor meer over deze brieven, zie: T. Wauters, 'De onuitgegeven Latijnse correspondentie van Hadriaan Beverland met Nicolaas Heinsius en Iacobus Gronovius in de universiteitsbibliotheken van Leiden en München' (Master Thesis Vrije Universiteit Brussel, 2000).

24. Beverland verwees vaak naar de woorden van de Romeinse dichter Martialis, die in zijn epigrammen meer dan eens benadrukte dat hij weigerde om de zaken heen te draaien. Zie bijvoorbeeld: Beverland, De Peccato, 151-154.

25. Voor meer over deze denkers, zie bijvoorbeeld: Wiep van Bunge, From Stevin to Spinoza: an essay on philosophy in the seventeenth-century Dutch Republic (Leiden: Brill, 2001), in het bijzonder 44-64, 74-82, 149-70; M. Wielema, The march of the libertines: Spinozists and the Dutch Reformed Church (1660-1750) (Proefschrift Vrije Universiteit Amsterdam, Hilversum: Verloren, 2004).

26. Zie: Lynn Hunt, 'Introduction', in Hunt, The Invention, 9-48; Margaret Jacob, 'The materialist world of pornography', in Hunt, The Invention, 157-202; James Grantham Turner, Schooling sex: libertine literature and erotic education in Italy, France, and England, 1534-1680 (Oxford: Oxford University Press, 2003), 1-30, 106-220; Leemans, Het Woord, 127-44, 233-76; Mijnhardt, 'Politics', 283-300.

27. Hij noemde hen bijvoorbeeld 'praevaricatores', 'buccones' en 'stipites' in zijn $D e$ Peccato, De Stolatae en 'De Prostibulis'.

28. Beverland, De Peccato, 151-154.

29. Ibidem, Pia Meditatio.

30. Beverland aan Dionysius Rechstood, 12/1679, in Universiteitsbibliotheek Leiden, Epistolae Tullianae, BPL 204, brief no. 33. Deze collectie brieven wordt van nu af aangeduid als ET. Voor meer over deze brieven zie: R. de Smet, 'Epistolae Tullianae. Brieven van Hadriaan Beverland', in De Gulden Passer, 64, 65, 68 (1986, 1987, 1990): 83-124, 70-101, 139-167.

31. Beverland aan Nicolaas Heinsius, ET 14, 15/10/1679. 


\section{Hollewand}

32. Beverland aan Jacob de Goyer, ET 14, 11/1679.

33. Beverland aan Heinsius, 20/11/1679, in Universiteitsbibliotheek Leiden, Beverlands Correspondentie met Nicolaas Heinsius, Burm. F 6a, brief no. 9. Deze collectie brieven wordt van nu af aangeduid als EH. Voor meer over deze brieven, zie: Wauters, 'De onuitgegeven Latijnse correspondentie'.

34. Beverland aan Heinsius, EH 9, 20/11/1679. De vertaling uit het Latijn komt uit: Wauters, 'De onuitgegeven Latijnse correspondentie'.

35. W.P.C. Knuttel (ed.), Acta der particuliere synoden van Zuid-Holland 1621-1700 (Den Haag: Martinus Nijhoff, 1908-16), Volume 5, 283.

36. Nationaal Archief, 'Gedrukte resoluties van de Staten van Holland', 3.01.04.01, B.1.1, $112,851$.

37. Beverland aan Jacob de Goyer, ET 21, 11/1679.

38. Beverland aan Heinsius, ET 14, 15/10/1679.

39. Beverland, De Peccato, 151-154. De quote komt uit Juvenalis, Satyra, boek XI, satire ll, regels 176-8.

40. Voor meer over Beverlands leven na zijn vrijlating, zie: Hollewand, The Banishment, 228-240. Voor meer over zijn rol als boeken- en kunsthandelaar, zie: Joyce Zelen, 'Blinded by Curiosity. The Collector-Dealer Hadriaan Beverland (1650-1716) and his Radical Approach to the Printed Image' (Radboud Universiteit Nijmegen PhD thesis, 2019).

41. 'Pardon William III', Zeeuwse Bibliotheek Middelburg, Ms 1713. Zie: R. de Smet, 'Traces of Hadriaan Beverland (1650-1716) in the Zeeuws documentatiecentrum at Middelburg, 1692-1715', in Lias: sources and documents relating to the early modern history of ideas, 19, no. 1 (1992): 73-91.

42. Zie ook: Hollewand, The Banishment, 230-240.

43. Beverland aan Gronovius, EG 33, 28/08/1694. De vertaling uit het Latijn komt uit: Wauters, 'De onuitgegeven Latijnse correspondentie.'

44. Beverland aan Gronovius, EG 35, 1695. De vertaling uit het Latijn komt uit: Wauters, 'De onuitgegeven Latijnse correspondentie.'

45. Zie: Inger Leemans, De sexshop van Europa. De Nederlandse productie en verspreiding van pornografische romans in de zeventiende eeuw', in Jaarboek voor Nederlandse boekgeschiedenis 7 (2000), 81-96; Leemans, Het Woord.

46. Beverland aan Alexander de Munck, ET 18, 11/1679.

47. Voor meer over de rol van verschillende partijen in zijn rechtszaak, zie: Hollewand, The Banishment.

48. Zie: F. Dabhoiwala, The origins of sex. A history of the first sexual revolution (London: Allen Lane, 2012).

49. De meeste bekende edities werden gepubliceerd door Bernard en Bertram: Jean Frédéric Bernard, (Histoire de) l'état (etat) de l'homme dans le péché (peché) originel (Paris, 1714, 1731, 1740, 1741, 1774); Philip Ernst Bertram, Philosophische Untersuchung von dem Zustand des Menschen in der Erbsünde (Leipzig, Frankfurt, 1746). Zie ook: Hollewand, The Banishment, 245-248, 265-267.

50. D. Van Hoogstraten, 'Op Beverlant', Gedichten (Amsterdam, 1697), 281. 